\title{
REACTION MIXTURES FORMED BY NITRITE AND SELECTED SULFA-DRUGS SHOWED MUTAGENICITY IN ACIDIC MEDIUM
}

Claudia Trossero, Ana Pontoriero, Estela Hure, Laura Monti, Carolina Gorr, Natalia Mosconi, Marcela Rizzotto*

Área Inorgánica, Facultad de Ciencias Bioquímicas y Farmacéuticas, Universidad Nacional de Rosario, Suipacha 531, 2000 Rosario, Argentina

Graciela Caffarena

Cátedra de Microbiología, Facultad de Ciencias Médicas, Universidad Nacional de Rosario, Av. Santa Fe 3100, 2000 Rosario, Argentina

Recebido em 29/4/08; aceito em 8/12/08; publicaod na web em 28/5/09

\begin{abstract}
Nitrite, which is present in preserved meat and can be produced in the oral cavity by reduction of nitrate taken from vegetables, could react in stomach with nitrosatable drugs, giving genotoxic-carcinogenic N-nitroso compounds (NOC). The mutagenicity of reaction mixtures formed by sodium nitrite and selected sulfa-drugs (sulfathiazole, HST; phtalylsulfathiazole, PhST; $\operatorname{complex} \mathrm{Co}(\mathrm{II})$ sulfathiazole, Co(II)-ST) in acidic medium was evaluated using the Salmonella typhimurium reverse mutation assay (Ames test), with TA98 and TA100 strains. The reactions were carried out at room temperature, with a mole ratio [nitrite]/[sulfa-drug] $\geq 1$. The three reaction mixtures showed mutagenic effects in the considered range.
\end{abstract}

Keywords: nitrite; sulfa-drugs; mutagenicity.

\section{INTRODUCTION}

Inorganic nitrates are primarily absorbed through the gastrointestinal system as a mixture of nitrates and nitrites. ${ }^{1}$ Nitrates are reduced to nitrites in saliva and in the gastrointestinal system. ${ }^{2}$ The nitrate reductase activity in the oral cavity appears to be influenced by seasonal conditions (it is higher at hot weather), and it is affected by $\mathrm{pH}$ too ( $\mathrm{pH} \cong 8$ is optimal). ${ }^{3}$ Salivary nitrite quantity can reach very high level (up to $1.26 \mathrm{mM}$ ) after consumption of nitrate-rich meals containing leafy and root vegetables. ${ }^{4}$ Since most saliva is swallowed, about $80 \%$ of gastric nitrite in the normal acidic stomach arises from the reduction of ingested or endogenous nitrate. The remaining $20 \%$ of gastric nitrite arises from ingested nitrite in nitrite-preserved meat and fish, water and other foods. ${ }^{5}$

The interaction of nitrite with substances containing functional $\mathrm{N}$ groups like amine, amide, etc., could generate genotoxic-carcinogenic $\mathrm{N}$-nitroso compounds (NOC) in the gastrointestinal tract. ${ }^{6,7} \mathrm{NOC}$ are unique among carcinogenic agents in being active in all species and in displaying a broad spectrum of target cells and organs in which they are able to induce cancer. The formation of NOC can occur in food (when preserved with nitrite), in the environment, and in the digestive tract (especially in the stomach, where the presence of $\mathrm{HCl}$ favours nitrosation reactions) from nitrosatable precursors and nitrosating agents. ${ }^{8}$ Considering this, intake of nitrosatable precursors for mutagens or carcinogens has received much attention because there is a good correlation between the amount of nitrate intake and gastric cancer mortality. NOC are considered to be a possible cause of human cancer. ${ }^{9}$ As reviewed by Mirvish, ${ }^{10} \mathrm{NOC}$ can be formed from secondary amines and amides. Because of the frequent presence in drugs of one or more of these groups, a large fraction of them, including natural products as aminoacids ${ }^{8}$ is theoretically nitrosatable. However, the problem of endogenous drug nitrosation is largely unrecognized. ${ }^{6}$

DNA damage is a critical factor in carcinogenesis. Many carcinogens initiate carcinogenesis by damaging DNA. ${ }^{11}$ Therefore, chemicals that cause mutations are often carcinogenic for humans, and they are mutagenic for bacteria as well as humans. ${ }^{12}$ A number

*e-mail: mrizzot@agatha.unr.edu.ar of different "short-term tests" have been developed to investigate the genotoxic properties of chemicals in food and the environment. ${ }^{13}$ The most widely used of these tests is the Ames test, ${ }^{14}$ which uses revertants of his mutations of Salmonella ssp. to detect mutations, both in single compounds or complex mixtures ${ }^{15}$ and in metal compounds too. ${ }^{16}$

The chemical is placed on a plate lacking histidine on which a His mutant of Salmonella has been spread. If the chemical can revert the his mutation, $\mathrm{His}^{+}$revertant colonies will appear on the plate. A number of different his mutations must be used because different mutagens cause different mutations and they all have preferred sites of mutagenesis. ${ }^{12}$

Sulfonamides (called sulfa-drugs too) are among the most widely used antibacterial agents in the world, chiefly because of their low cost, low toxicity and excellent activity against bacterial diseases. ${ }^{17}$ Sulfonamides are extensively used as veterinary drugs too, so, they could be found as contaminants both in the environment ${ }^{18}$ or food ${ }^{19}$ and it is common to find them together with nitrites and nitrates in groundwaters. ${ }^{20}$ After the introduction of penicillin and other antibiotics, the popularity of sulfonamides decreased. However, they are still considered useful in certain therapeutic fields, especially in the case of ophthalmic infections as well as infections in the urinary and gastrointestinal tract. Besides, sulfadrugs are still today among the drugs of first election (together with ampicillin and gentamycin) as chemotherapeutic agents in bacterial infections by Escherichia coli in humans. ${ }^{21}$ Recently, the use of sulfonamides and their derivatives are in renascence because their multiple pharmacological properties. ${ }^{22}$ The sulfanilamides exert their antibacterial action by the competitive inhibition of the enzyme dihydropterase synthetase towards the substrate p-aminobenzoate. ${ }^{23}$

However, one risk of sulfonamides is that they are theoretically nitrosatable due to the presence of amine and/or amide functions in their molecules. In this paper we investigate the mutagenicity of reaction mixtures formed by selected sulfa-drugs and nitrite in acidic medium. The selected sulfonamides were: sulfathiazole (4-amino-N-2-thiazolylbencenosulfonamide), HST, which in part is absorbed in stomach, ${ }^{21}$ and is clinically one of the most used; ${ }^{24}$ phtalylsulfathiazole, $\mathrm{PhST}$, which is structurally related with HST (Figure 1) and the complex Co(II)- 
sulfathiazole, $\mathrm{Co}(\mathrm{II})-\mathrm{ST}$ : $\left[\mathrm{Co}(\mathrm{ST})_{2}\left(\mathrm{H}_{2} \mathrm{O}\right)_{4}\right]$, which was lately synthesized in our laboratory and has showed a moderated antifungal activity. ${ }^{25}$

(a)<smiles>Nc1ccc(S(=O)(=O)Nc2nccs2)cc1</smiles>

(b)

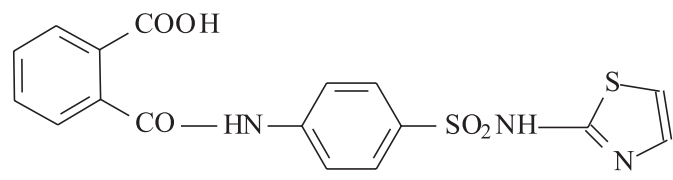

Figure 1. Structure of sulfathiazole (a) and phtalylsulfathiazole (b)

\section{EXPERIMENTAL}

\section{Materials}

Sulfathiazole, as sodium salt (NaST), Sigma 99\%; phtalylsulfathiazole (PhST), Argentinean Pharmacopoeia grade; sodium nitrite, Mallinckrodt; 2-aminofluorene (2-AF), Aldrich 98\%; sodium azide, Aldrich $99 \%$ and all other chemicals, of commercially available reagent grade, were used as received. The complex Co(II)-ST was synthesized by us as described previously. ${ }^{25}$

\section{Preparation of culture medium}

Nutrient broth was prepared by dissolving $25 \mathrm{~g}$ of Bacto-Difco nutrient broth in 1 liter of water. Glucose minimal agar plate (MA plate) contained $1.5 \%$ agar, $0.02 \% \mathrm{MgSO}_{4} \cdot 7 \mathrm{H}_{2} \mathrm{O}, 0.2 \%$ citric acid, $1 \% \mathrm{~K}_{2} \mathrm{HPO}_{4}, 0.35 \% \mathrm{NaHNH}_{4} \mathrm{PO}_{4} \cdot 4 \mathrm{H}_{2} \mathrm{O}$ and $2 \%$ glucose. Top agar contained $0.75 \%$ agar and $0.5 \% \mathrm{NaCl}^{2}$.

\section{Preparation of rat liver microsomal enzymes and cofactors (S-9 mix)}

S-9 mix was prepared followed the method of Maron and Ames. ${ }^{14} \mathrm{~S}-9$ mix was obtained of the postmitochondrial fraction of liver from a rat (Wistar strain without induction, weigh: $250 \mathrm{~g}$, one year old, obtained from the rat farm at the Faculty of Medicine, University of Rosario). Before each test, each vial of S-9 mix was reconstituted to $2.1 \mathrm{~mL}$ by adjusting $\mathrm{S}-9 \mathrm{mix}$ to final concentration of $4 \%$ with dilution buffer containing $0.004 \mathrm{M}$ phosphate buffer (pH 7.4), 0.008 $\mathrm{M} \mathrm{MgCl}_{2}, 0.033 \mathrm{M} \mathrm{KCl}, 0.004 \mathrm{M}$ NADP, and 0.05 M D-glucose-6-phosphate (G-6-P). The S-9 mix was fresh prepared for each assay, and it was discarded if the duration exceeded $4 \mathrm{~h}$. A volume of $0.5 \mathrm{~mL}$ of the S-9 mix was added per plate for the positive control of the TA98 strain with 2-AF.

\section{Reaction of the sulfa-drugs with sodium nitrite in acidic medium: general procedure}

After several attempts, we selected the following conditions for the reaction: reaction temperature: room temperature $\left(25^{\circ} \mathrm{C}\right)$; $[\mathrm{HCl}]_{\text {final }}: 1 \mathrm{M}(\mathrm{pH}=0)$; reaction time (previous to dilution, see later): $5 \mathrm{~min}$. The initial mole ratio $\left[\mathrm{NaNO}_{2}\right] /[$ sulfa-drug] was different for each system, i.e.: "A" system: sodium nitrite + sulfathiazole, 1/1; "B" system: sodium nitrite + phtalylsulfathiazole, $4 / 1$; "C" system: sodium nitrite $+\mathrm{Co}(\mathrm{II})$-sulfathiazole, $3 / 1$. In a typical experience, 3.2 mmol of hydrochloric acid $(0.27 \mathrm{~mL} \mathrm{HCl} 37 \%$, density: $1.18 \mathrm{~g} / \mathrm{mL})$ was added to $2.7 \mathrm{~mL}$ of a DMSO solution formed by $0.0541 \mathrm{mmol}$ of the studied sulfa-drug (i.e.: sodium sulfathiazole, NaST: $15.0 \mathrm{mg}$; phthalylsulfathiazole, PhST: $21.8 \mathrm{mg}$; complex Co(II)-sulfathiazole, $\mathrm{Co}(\mathrm{II})-\mathrm{ST}: 33.6 \mathrm{mg}$ ) and a quantity of sodium nitrite, $\mathrm{NaNO}_{2}$, between 0.0541 and $0.216 \mathrm{mmol}$ (i.e.: $4.0-16.0 \mathrm{mg}$ ), in agreement with each selected mole ratio, at room temperature. Immediately the reaction mixture, under continuous stirring, became yellow-orangey. $5 \mathrm{~min}$ later it was diluted 1:20 with sterile distilled water. The assayed doses (10 to $90 \mu \mathrm{L}$ ) were taken from each aqueous diluted mixture. " $\mathrm{D}$ " system, which is not a reaction one, was included in order to analyze the mutagenicity of the complex Co(II)-ST alone. In a typical experience, $33.6 \mathrm{mg}$ of $\mathrm{Co}(\mathrm{II})-\mathrm{ST}$ were dissolved in $3.00 \mathrm{~mL}$ of DMSO. Later, this solution was diluted 1:20 with sterile distilled water. The assayed doses (10 to $100 \mu \mathrm{L}$ ) were taken from this diluted mixture.

Similar set of reactions was made at $\mathrm{pH}$ range from 0.5 to 2 in hydrochloric aqueous solutions of each sulfa-drug. This range of $\mathrm{pH}$ was selected in order to approach to the stomach $\mathrm{pH}, \cong 1.5-2 .{ }^{26} \mathrm{PhST}$ and $\mathrm{Co}(\mathrm{II})-\mathrm{ST}$, which are insoluble in water, were dissolved in the minimum quantity of DMSO. The $\mathrm{pH}$ was measured with a Metrohm GB4-350B pHmeter equipped with glass combination electrode. The reaction mixture became yellow-orangey immediately after the addition of aqueous solution of $\mathrm{NaNO}_{2}$.

\section{Mutagenicity assay}

Mutagenicity activity was evaluated in a bacterial reverse mutation assay by the standard Ames test (standard plate incorporation assay) with TA98 and TA100 strains ${ }^{14,27}$ by using the Salmonella typhimurium histidine-requiring test strains TA98 and TA100, which together detect the $93 \%$ of the mutagens. ${ }^{28}$

Diagnostic mutagens, including 2-aminoflourene, 2-AF (5.53 $\mu \mathrm{g} /$ plate) with metabolic system (rat liver homogenated S-9 mix) for the TA98 strain $(850 \pm 23$ revertants/plate) and sodium azide, $\mathrm{NaN}_{3}(0.15 \mu \mathrm{g} /$ plate $)$ for the TA100 one $(358 \pm 20$ revertants/ plate), were prepared by dissolving them in DMSO and sterile water respectively, and served as positive control chemicals. Doseresponse curves were generated for each reaction mixture using the standard plate assay, in the absence of S-9 mix. Bacteria were aerobically grown at $37^{\circ} \mathrm{C}$ in Nutrient Broth Bacto-Difco. The test was carried out by adding $0.2 \mathrm{~mL}$ of sterile $0.5 \mathrm{mM}$ histidine-biotin and $0.1 \mathrm{~mL}$ of the overnight bacterial culture (approximately 1 x $10^{8}$ bacteria/mL) to $2.0 \mathrm{~mL}$ of molten top agar $\left(45^{\circ} \mathrm{C}\right)$. Doses from 10 to $90-100 \mu \mathrm{L}$ of the tested mixtures were added to top agar tubes, which were then gently vortexed and subsequently transferred to plates with minimal glucose agar $(30 \mathrm{~mL} / \mathrm{plate})$. Duplicate plates were poured for each dose of reaction mixture in at least two independent experiments. After incubation at 37 ${ }^{\circ} \mathrm{C}$ for $48 \mathrm{~h}$ in darkness, the His ${ }^{+}$revertant colonies were manually counted.

If chemicals tested for mutagenicity show toxicity (antimicrobial activity) against the tester strains, an erroneous result could be obtained when the Salmonella typhimurium test (Ames test) is employed. ${ }^{14}$ After several attempts, such an optimal initial concentration of each reaction mixture was obtained that approximately the first four or five doses tested were included in the incremental part of the curve dose-response. In the toxic range of the curve a decrease in the number of revertants per plate can be observed. Neither toxicity nor mutagenicity was observed for both $\mathrm{NaNO}_{2}$ and $\mathrm{CoCl}_{2} \cdot 6 \mathrm{H}_{2} \mathrm{O}$ in the tested range. As it has been proved that sulfa-drugs are not mutagenic, ${ }^{29}$ the activity of the sulfa-drugs employed in this study was not tested by us. 
Regression equations and correlation coefficients were calculated in accordance with routine statistical methods. All data were expressed as mean \pm standard deviation (S.D.). ${ }^{30}$

\section{RESULTS AND DISCUSSION}

The results of the Ames test for both the reaction mixtures and the complex Co(II)-ST are shown in Tables 1-3 and Figure 2.

The reversion coefficient (R.C.), ${ }^{31}$ also known as mutagenicity ratio, ${ }^{32}$ has been defined as follows: revertant number per tested plate/ revertant number per control plate (spontaneous). i.e.: dividing the average revertants/plate of the tested substance by the spontaneous mutation rate. ${ }^{32}$ A non-statistical procedure has been established to evaluate the results of Salmonella experiments. ${ }^{27,33}$ In agreement with this procedure, a substance (pure or mixture) is considered a mutagen if it produces a reproducible, dose-related increase in the number of revertant colonies in one or more strains (i.e.: R.C. $\geq 2.0$ ). A substance is considered a weak mutagen if it produces a reproducible, doserelated increase in the number of revertant colonies in one or more strains but the number of revertants is not double the background number of colonies. Although it is generally accepted that a negative result can be defined using 4-5 tester strains and strains TA98 and TA100 are always considered necessary, a single strain is sufficient to demonstrate a mutagenic response. ${ }^{14}$ Consistent with this, all of the tested reaction mixtures are mutagenic: "A" and "B" toward both strains and "C" toward the TA98 one (Tables 1 and 2). In order to compare, we calculated the R.C. for each tested doses (Tables 1-3) and plotted them vs. the concentration of the tested compounds. Regression equations, as well as linear correlation coefficients of the dose-response direct-line relation and the maximum R.C. obtained for each substance in the range tested dose, are presented in Figure 2. As may be noticed, in some cases the lines of the dose-response relation fit the direct-line relation with a high correlation coefficient and, in other cases such a correlation is low. The differences were particularly striking in the case of the " $\mathrm{A}$ " reaction mixture, where it is possible to observe R.C $\leq 1$ corresponding to the early points of the dose-response curve for both strains. This could be due to two possible opposite factors acting on growing of the tester strain: toxicity and mutagenic effects, and could be more evident for TA100 owing to the higher sensibility of this strain to the killing effects of the chemicals than that of TA98. ${ }^{28}$

Sulfonamides have nitrosable functions in their molecules, so, they could react with nitrite in acidic medium giving direct mutagen acting. The tester strains used detect two different types of mutational DNA change, i.e.: frame shift (TA98) and base substitutions (TA100) ${ }^{14}$ In agreement with this fact, it can be observed that both "A" and "B" reaction mixtures would be able to generate both types of DNA changes: C.R. exceeded 2.00 in both TA98 and TA100 experiments. There are many examples of reaction mixtures formed by nitrite and nitrosatable drugs in which mutagenicity of the whole mixture toward both TA98 and TA100 strains has been observed. ${ }^{34}$ On the other hand, Endo et al. found that the incubation of sulfanilamide (a sulfa-drug) with $\mathrm{NaNO}_{2}$ in human gastric juice produced a transplacental mutagen. This reaction took place under a broad range of conditions (in acetate buffer - $\mathrm{pH}$ approximately 4- at 37 ${ }^{\circ} \mathrm{C}$ as well as in hydrochloric acid: $\mathrm{pH}<1$ and under ice cooling).$^{35}$ Besides, the reaction mixture of thiamine (a vitamin) and nitrite at pH 3 showed mutagenicity on TA100 strain but not on the TA98 one. Thiamine bears an aminopyrimidine moiety in its structure, so, it may be converted into diazotized or nitro compounds with direct-acting mutagenicity by interaction with nitrite. ${ }^{9}$ Nitrosation of bile acid conjugates can be mediated by the acid-catalyzed reaction of amides with nitrite. ${ }^{36} \mathrm{~N}$-nitroso bile acid conjugates induced revertants on TA100, which detects base pairs change mutations, but not with TA98, a detector of frame-shift mutations. ${ }^{37}$ With the " $C$ " reaction mixture, the behavior was different from " $A$ " and " $B$ "

Table 1. Mutagenic activity of the reaction mixtures in $\mathrm{HCl} 1 \mathrm{M}$ with S. typhimurium TA98

\begin{tabular}{lccc}
\hline $\begin{array}{l}\text { Tested } \\
\text { substances }\end{array}$ & $\begin{array}{c}\text { Dose } \\
(\mu \mathrm{g} / \text { plate })^{\mathrm{a}}\end{array}$ & revertants/plate & R.C. \\
\hline $\begin{array}{l}\mathrm{NaNO}_{2}+\mathrm{NaST} \\
1 / 1^{\mathrm{d}}\end{array}$ & $0^{\mathrm{e}}$ & $15 \pm 1$ & 1.00 \\
(“"A" system) & & $15 \pm 2$ & 1.00 \\
& 2.5 & $17 \pm 1$ & 1.13 \\
& 5.0 & $19 \pm 2$ & 1.27 \\
& 7.5 & $25 \pm 3$ & 1.67 \\
& 10.0 & $44 \pm 4$ & 2.93 \\
& 12.5 & $10 \pm 2$ & 0.70 \\
& 15.0 & $7 \pm 1$ & 0.47 \\
& 17.5 & $1 \pm 1$ & 0.07 \\
& 22.5 & &
\end{tabular}

$\begin{array}{lccc}\begin{array}{l}\mathrm{NaNO}_{2}+\mathrm{PhST} \\ 4 / 1^{\mathrm{d}}\end{array} & 0^{\mathrm{e}} & 10 \pm 1 & 1.00 \\ \text { (“B” system) } & & 18 \pm 1 & 1.80 \\ & 7.3 & 18 \pm 2 & 1.80 \\ & 10.9 & 20 \pm 2 & 2.00 \\ & 14.5 & 21 \pm 2 & 2.10 \\ & 18.2 & 18 \pm 1 & 1.80 \\ & 21.8 & 18 \pm 2 & 1.80 \\ & 25.4 & 18 \pm 2 & 1.80 \\ & 32.7 & \end{array}$

$\mathrm{NaNO}_{2}+$

$\begin{array}{llll}\mathrm{Co}(\mathrm{II})-\mathrm{ST} & 3 / 1^{\mathrm{d}} & 0^{\mathrm{e}} & 10 \pm 1\end{array}$

(“C” system)

$\begin{array}{ccc}5.6 & 9 \pm 1 & 0.90 \\ 11.2 & 19 \pm 2 & 1.90 \\ 16.8 & 20 \pm 3 & 2.00 \\ 22.4 & 25 \pm 2 & 2.50 \\ 28.0 & 11 \pm 1 & 1.10 \\ 33.6 & 11 \pm 1 & 1.10 \\ 39.2 & 12 \pm 1 & 1.20 \\ 50.4 & 13 \pm 2 & 1.30\end{array}$

2-aminofluorene $(2-A F)^{\mathrm{f}}$

$5.53 \quad 850 \pm 23$

56.7

ainitial $\mu \mathrm{g}$ of sulfa-drug/plate. ${ }^{\mathrm{b}}$ mean \pm S.D. ${ }^{\mathrm{c}}$ R.C.: reversion coefficient $=$ revertants with tested substance/spontaneous revertants. dinitial mole ratio $\left[\mathrm{NaNO}_{2}\right] /\left[\right.$ sulfa-drug]. ${ }^{\mathrm{e}}$ Negative control, without tested compounds, only with $50 \mu \mathrm{L}$ DMSO: spontaneous revertants/

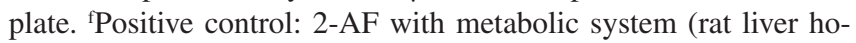
mogenated S-9 mix). 
Table 2. Mutagenic activity of the reaction mixtures in $\mathrm{HCl} 1 \mathrm{M}$ with S. typhimurium TA100

\begin{tabular}{lccc}
\hline $\begin{array}{l}\text { Tested } \\
\text { substances }\end{array}$ & $\begin{array}{c}\text { Dose } \\
(\mu \mathrm{g} / \text { plate })^{\mathrm{a}}\end{array}$ & revertants/plate $^{\mathrm{b}}$ & R.C. $^{\mathrm{c}}$ \\
\hline & & & \\
$\mathrm{NaNO}_{2}+\mathrm{NaST}$ & $0^{\mathrm{e}}$ & $83 \pm 6$ & 1.00 \\
$\begin{array}{l}1 / 1^{\mathrm{d}} \\
\text { (“A” system) }\end{array}$ & 2.5 & $74 \pm 7$ & 0.89 \\
& 5.0 & $79 \pm 8$ & 0.95 \\
& 7.5 & $181 \pm 20$ & 2.18 \\
& 12.5 & $123 \pm 12$ & 1.48 \\
& 17.5 & $117 \pm 10$ & 1.41 \\
& 25.0 & $75 \pm 7$ & 0.90
\end{tabular}

\section{$\mathrm{NaNO}_{2}+\mathrm{PhST}$}

$4 / 1^{\text {d }}$

$$
0^{\mathrm{e}}
$$$$
210 \pm 16
$$

("B" system)

$\begin{array}{ccc}3.6 & 366 \pm 24 & 1.74 \\ 7.3 & 452 \pm 24 & 2.15 \\ 10.9 & 494 \pm 26 & 2.35 \\ 18.2 & 183 \pm 19 & 0.87 \\ 21.8 & 177 \pm 19 & 0.84 \\ 25.4 & 212 \pm 18 & 1.01 \\ 29.1 & 200 \pm 24 & 0.95 \\ 32.7 & 67 \pm 6 & 0.32\end{array}$

$\mathrm{NaNO}_{2}+$

Co(II)-ST 3/1

$0^{\mathrm{e}}$

$113 \pm 11$

1.00

("C" system)

$\begin{array}{ccc}5.6 & 110 \pm 10 & 0.97 \\ 11.2 & 105 \pm 9 & 0.93 \\ 16.8 & 94 \pm 9 & 0.83 \\ 22.4 & 94 \pm 8 & 0.83 \\ 28.0 & 98 \pm 8 & 0.87 \\ 39.2 & 80 \pm 6 & 0.71 \\ 50.4 & 87 \pm 8 & 0.77\end{array}$

sodium azide

$\left(\mathrm{NaN}_{3}\right)^{\mathrm{f}}$

$0.15 \quad 358 \pm 20$

3.17

${ }^{a}$ initial $\mu \mathrm{g}$ of sulfa-drug/plate. ${ }^{b}$ mean \pm S.D. ${ }^{c}$ R.C.: reversion coefficient $=$ revertants with tested substance/ spontaneous revertants. dinitial mole ratio $\left[\mathrm{NaNO}_{2}\right] /\left[\right.$ sulfa-drug]. ${ }^{\mathrm{e} N e g a t i v e ~ c o n t r o l, ~ w i t h o u t ~}$ tested compounds, only with $50 \mu \mathrm{L}$ DMSO: spontaneous revertants/ plate. fPositive control.

systems: R.C. exceeded the value of 2.00 only for the TA98 strain. In the "C" system the sulfa-drug is a Co(II) complex. Besides, it is probably that more than one specie $\mathrm{Co}$ (II)-sulfatiazole could be present in the acidic solution; for example, $[\mathrm{Co}(\mathrm{ST})]^{+}$was found at $\mathrm{pH} \approx 3$ by potentiometric measurements. ${ }^{38}$
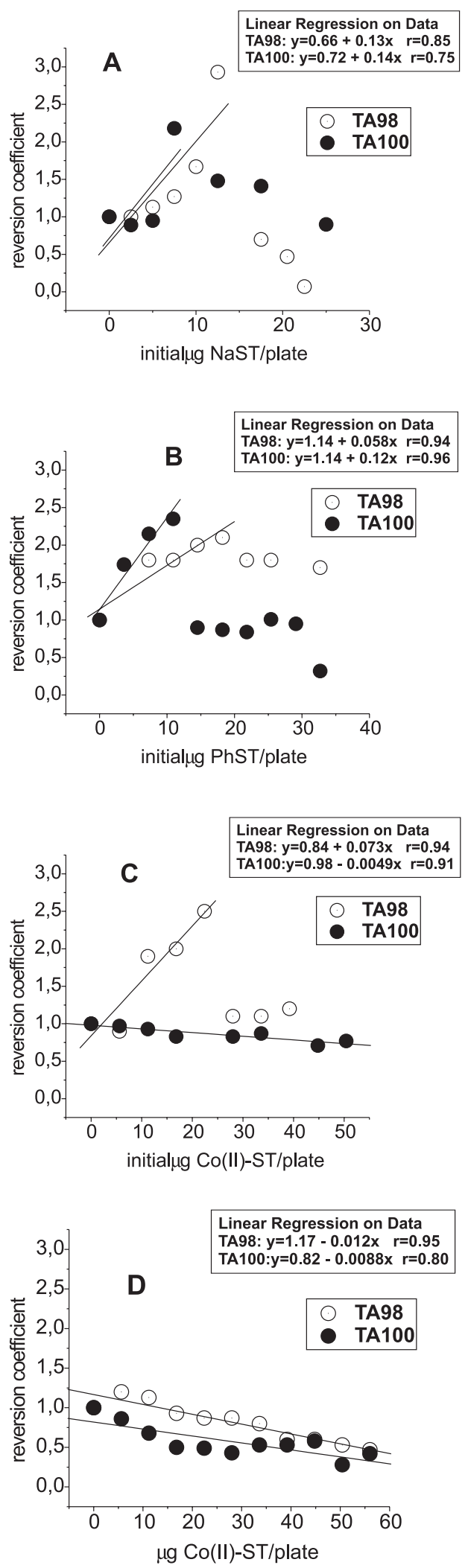

Figure 2. Effect of the concentration of the tested substances on the reversion coefficient toward TA98 and TA100 tester strains. The results of each reaction mixture in acidic medium $\left([\mathrm{HCl}]_{\text {fnal }}: 1 \mathrm{M}\right)$ and the parent compound Co(II)-ST are presented separately (A-D), i.e.: A: sodium nitrite + sulfathiazole; B: sodium nitrite + phtalylsulfathiazole; $C$ : sodium nitrite + Co(II)-sulfathiazole, D: complex Co(II)-ST (in DMSO:water 1:20). Regression lines and regression equations describing dose-response relationship of the mutagenic activity of tested mixtures are shown 
It has been suggested a slight antimutagenic activity of cobalt. ${ }^{39}$ $\mathrm{Co}^{2+}$ ion is also an example of inhibitors of NOC-induced mutagenicity that act subsequent to the induction of primary DNA lesions and prevent the manifestation of DNA damage by modulating DNA repair. ${ }^{40}$ Taken these facts into account, the presence of $\mathrm{Co}$ (II) probably would be involved in the different behavior of the " $\mathrm{C}$ " reaction mixture toward TA100 with respect to the "A" and "B" ones. Work is in progress in order to confirm this hypothesis.

The complex Co(II)-ST ("D" system) showed a slight toxicity toward both strains in the tested range (Table 3), so, it is not possible to say anything about its mutagenicity from these experiments. In the "A", "B" and "C" systems a progressive decay of the R.C. values was observed at the highest doses (after reaching a maximum one), which could be a manifestation of toxicity too.

Table 3. Mutagenic activity of the complex Co(II)-ST ("D" system) with S. typhimurium TA98 and TA100

\begin{tabular}{|c|c|c|c|}
\hline \multicolumn{4}{|c|}{ Mean number of revertants/plate \pm S.D. $(\text { R.C. })^{\mathrm{a}}$} \\
\hline Dose $(\mu \mathrm{g} /$ plate $)$ & TA98 & TA10 & \\
\hline $0^{\mathrm{b}}$ & $15 \pm 2 \quad(1.00)$ & $113 \pm 11$ & $(1.00)$ \\
\hline $5.6^{\mathrm{c}}$ & $18 \pm 2 \quad(1.20)$ & $97 \pm 8$ & $(0.85)$ \\
\hline $11.2^{\mathrm{c}}$ & $17 \pm 1$ & $77 \pm 7$ & $(0.68)$ \\
\hline $16.8^{\mathrm{c}}$ & $14 \pm 1 \quad(0.93)$ & $57 \pm 5$ & $(0.50)$ \\
\hline $22.4^{\mathrm{c}}$ & $13 \pm 1 \quad(0.87)$ & $49 \pm 5$ & $(0.43)$ \\
\hline $28.0^{\mathrm{c}}$ & $13 \pm 1 \quad(0.87)$ & $60 \pm 6$ & $(0.53)$ \\
\hline $33.6^{\mathrm{c}}$ & $12 \pm 1 \quad(0.80)$ & $60 \pm 5$ & $(0.53)$ \\
\hline $39.2^{\mathrm{c}}$ & $9 \pm 1 \quad(0.60)$ & $65 \pm 7$ & $(0.57)$ \\
\hline $50.4^{\mathrm{c}}$ & $8 \pm 1 \quad(0.53)$ & $32 \pm 3$ & $(0.28)$ \\
\hline $56.0^{c}$ & $7 \pm 1 \quad(0.47)$ & $47 \pm 4$ & $(0.42)$ \\
\hline $2-A F(5.53)^{d}$ & $850 \pm 23(56.7)$ & - & \\
\hline $\mathrm{NaN}_{3}(0.15)^{\mathrm{d}}$ & - & $358 \pm 20$ & $(3.17)$ \\
\hline $\begin{array}{l}\text { R.C.: reversion } \\
\text { spontaneous reve } \\
\text { pounds, only wit } \\
{ }^{\mathrm{c}} \mu \mathrm{g} \text { of the compl } \\
2-\mathrm{AF} \text { with metab }\end{array}$ & $\begin{array}{l}\text { nt }=\text { revertants } \mathrm{w} \\
\text { Negative control: } \\
\text { DMSO; spontan } \\
\text {-ST/plate. }{ }^{\mathrm{d}} \text { Posit } \\
\text { tem: rat liver hon }\end{array}$ & $\begin{array}{l}\text { sted substa } \\
\text { hout tested } \\
\text { revertants/ } \\
\text { ontrols (for } \\
\text { nated S-9 n }\end{array}$ & $\begin{array}{l}\text { ance/ } \\
\text { com- } \\
\text { /plate. } \\
\text { or TA98: } \\
\text { mix). }\end{array}$ \\
\hline
\end{tabular}

\section{CONCLUSION}

Reaction mixtures formed by sodium nitrite and selected sulfadrugs (sulfathiazole, phtalylsulfathiazole, Co(II)-sulfathiazole) in acidic medium showed mutagenic effects toward the Ames test. However, further experiments are required for a final evaluation of the risk of those mixtures into the human body.

\section{ACKNOWLEDGEMENTS}

We thank the National University of Rosario and its Research Council (CIUNR) for financial support. M.R. is member of the Carrera del Investigador CIC-UNR.

\section{REFERENCES}

1. Bouchard, D.; Williams, M.; Surampalli, R.; J.-Am. Water Works Assoc. 1992, 84,85 .
2. Hartman, P. In Chemical Mutagens; De Serres, F. J.; Hollaender, A., eds.; Plenum Publishing Corp.: New York, 1982, cap. 7; Ridder, W.; Oehme, F.; Clin. Toxicol. 1974, 7, 145.

3. Xu, J.; Xu, X.; Verstraete, W.; Food Chem. Toxicol. 2001, 39, 393.

4. Kowalski, B.; Miller, C.; Sen, N.; IARC Sci. Publ. 1980, 31, 609.

5. Mirvish, S.; J. Natl. Cancer Inst. 1983, 71, 629.

6. Brambilla, G.; Martelli, A.; Mutat. Res., Rev. Mutat. Res. 2007, 635, 17.

7. Pietraforte, D.; Brambilla, G.; Camerini, S.; Scorza, G.; Peri, L.; Loizzo, A.; Crescenzi, M.; Minetti, M.; Free Radical Biol. Med. 2008, 45, 124.

8. García-Santos, M.; González-Mancebo, S.; Hernández-Benito, J.; Calle, E.; Casado, J.; J. Am. Chem. Soc. 2002, 124, 2177.

9. Hiramoto, K.; Ni-Iyama, H.; Kato, T.; Kikugawa, K.; Jpn. J. Toxicol. Environ. Health 1995, 41, 447.

10. Mirvish, S.; Toxicol. Appl. Pharmacol. 1975, 31, 325.

11. Imani, K.; Mochizuki, M.; Mutat. Res. 2002, 519, 133.

12. McCann, J.; Ames, B.; Proc. Natl. Acad. Sci. U.S.A. 1976, 73, 950.

13. Fratianni, F.; Di Luccia, A.; Coppola, R.; Nazzaro, F.; Food Chem. 2007, 102, 471; Kummrow, F.; Umbuzeiro, G. de A.; Quim. Nova 2008, 31, 401.

14. Maron, D.; Ames, B.; Mutat. Res. 1983, 113, 173.

15. Aufderheide, M.; Gressmann, H.; Mutat. Res., Genet. Toxicol. Environ. Mutagen. 2008, 656, 82.

16. Josephy, P. D.; Weadge, J. J.; Meissner, J.; Ng, F.; Mutat. Res., Genet. Toxicol. Environ. Mutagen. 2008, 654, 64.

17. Ajibade, P.; Kolawole, G.; O’Brien, P.; Helliwell, M.; Raftery, J.; Inorg. Chim. Acta 2006, 359, 3111.

18. Raich-Montiu, J.; Folch, J.; Compañó, R.; Granados, M.; Prat, M.; J. Chromatogr., A 2007, 1172, 186.

19. Zheng, M-M.; Zhang, M-Y.; Peng, G-Y.; Feng, Y-Q.; Anal. Chim. Acta 2008, 625, 160 .

20. Batt, A.; Snow, D.; Diana, S.; Aga, D.; Chemosphere 2006, 64, 1963.

21. Mandell, G.; Sande, M. In Las bases farmacológicas de la terapéutica; Goodman, A.; Gilman, L., eds.; Editorial Médica Panamericana: Buenos Aires, 1981, cap. 49.

22. Ezabadi, I.; Camoutsis, C. ; Zoumpoulakis, P. ; Geronikaki, A.; Soković, M.; Glamocilija, J.; Cirić, A.; Bioorg. Med. Chem. 2008, 16, 1150; Mondelli M, Bruné V, Borthagaray, G. ; Ellena, J.; Nascimento, O.; Leite, C.; Batista, A.; Torre, M.; J. Inorg. Biochem. 2008, 102, 285; Özmen, Ü.; Olgun, G.; Spectrochim. Acta, Part A 2008, 70, 641; Bellú, S.; Hure, E.; Trapé, M.; Rizzotto, M.; Sutich, E. ; Sigrist, M.; Moreno, V.; Quim. Nova 2003, 26, 188; Massah, A. R.; Adibi, H.; Khodarahmi, R.; Abiri, R.; Majnooni, M. B.; Shahidi, S.; Asadi, B.; Mehrabi, M.; Zolfigol, M. A.; Bioorg. Med. Chem. 2008, 16, 5465; da Silva, L. E.; de Sousa Jr., P. T.; Joussef, A. C.; Piovezan, C.; Neves, A.; Quim. Nova 2008, 31, 1161.

23. García-Raso, A.; Fiol, J.; Rigo S.; López-López, A., Molins, E.; Espinosa, E.; Borrás, E.; Alzuet, G.; Borrás, J.; Castiñeira, A.; Polyhedron 2000, 19, 991.

24. Casanova, J.; Alzuet, G.; Borrás, J.; David, L.; Gatteschi, D.; Inorg. Chim. Acta 1993, 211, 183.

25. Bellú, S.; Hure, E.; Trapé, M.; Trossero, C. ; Molina, G.; Drogo, C.; Williams, P.; Atria, A.; Muñoz Acevedo, J.; Zacchino, S.; Sorino, D.; Campagnoli, D.; Rizzotto, M.; Polyhedron 2005, 24, 501.

26. Cova, D.; Nebuloni, C.; Arnoldi, A.; Bassoli, A.; Trevisan, M.; Del Re, A.; J. Agric. Food Chem. 1996, 44, 2852.

27. Mortelmans, K.; Zeiger, E.; Mutat. Res. 2000, 455, 29.

28. Jurado, J.; Alejandre-Durán, E.; Pueyo, C.; Mutagenesis 1993, 8, 527.

29. Zeiger, E.; Anderson, B.; Haworth, S.; Lawlor, T.; Mortelmans, K.; Environ. Mol. Mutagen. 1988, 11, 1.

30. Bourke, G.; Daly, L.; McGilvray, J. In Interpretation and Uses of Medical Statistics; Bourke, G., Ed.; Blackwell Scientific Publications: Oxford 1985, p. 131; Liao, J-W.; Chung, Y-C.; Yeh, J-Y.; Lin, Y-C.; Lin, Y-G.; Wu, S-M.; Chan, Y-C.; Food Chem. Toxicol. 2007, 45, 1393. 
31. Gasiorowski, K.; Szyba, K.; Urban, J.; Cieslak-Golonka, M.; Zakeeruddin, S.; Grätzel, M.; Fraser. D.; BioMetals 1995, 8, 257.

32. Crebellia, R.; Contia, L.; Monarcab, S.; Ferettib, D.; Zerbinib, I.; Zanib, C.; Veschettic, E.; Cutillic, D.; Ottaviani, M.; Water Res. 2005, 39, 1105.

33. Zeiger, E.; Anderson, B.; Haworth, S.; Lawlor, T.; Mortelmans, K.; Environ. Mol. Mutagen. Mutagen. 1992, 19, 1.

34. Ohta, T.; Oribe, H.; Kameyama, T.; Goto, Y.; Takitani, S.; Mutat. Res. Lett. 1988, 209, 95; Kikugawa, K.; Kato, T.; Takeda, Y.; Mutat. Res., Fundam. Mol. Mech. Mutagen. 1987, 177, 35; Andrews, A.; Lijinsky, W.; Snyder, S.; Mutat. Res., Genet. Toxicol. Environ. Mutagen. 1984, 135, 105; Pan, X.; San Francisco, M. J.; Lee, C.; Ochoa, K. M.; Xu, X.; Liu, J.; Zhang, B.; Cox, S. B.; Cobb, G. P.; Mutat. Res., Genet. Toxicol. Environ. Mutagen. 2007, 629, 64.
35. Endo, H.; Noda, H.; Kinoshita, N.; Inui, N.; Nishi, Y.; J. Natl. Cancer Inst. 1980, 65, 547.

36. Shuker, D.; Tannenbaum, S.; Wishnok, J.; J. Org. Chem. 1981, 46, 2092.

37. Totsuka, Y.; Nishigaki, R.; Enomoto, S.; Takamura-Enya, T.; Masumura, K.; Nohmi, T.; Kawahara, N.; Sugimura, T.; Wakabayashi, K.; Chem. Res. Toxicol. 2005, 18, 1553.

38. Bellú, S.; Rizzotto, M.; Okulik, N.; Jubert, A.; Quim. Nova 2007, 30, 1136 .

39. Hartwig, A.; Snyder, R.; Schlepegrell, R.; Beyersmann, D.; Mutat. Res., Fundam. Mol. Mech. Mutagen. 1991, 248, 177.

40. Cai, H. Y. In Relevance to human cancer of $N$-nitroso compounds, tobacco smoke and mechanisms; O’Neill, I. K.; Chen, J.; Bartsch, H., eds. IARC: Sci. Publ. 1991, 105, 579. 